\title{
Equal education for All: Reaching for the Mirage in Some South African Schools
}

\author{
Maura Mbunyuza-de Heer Menlah \\ Department of Curriculum \& Instructional Studies \\ UNISA, PO BOX 392, UNISA, 0003 \\ mbunynmm@unisa.ac.za
}

\section{Doi:10.5901/mjss.2014.v5n9p392}

\begin{abstract}
Education is one of the areas that the government of South Africa has identified in the delivery of promise to bring about equality for all. It is a tool through which people should be prepared to participate in the global village thus it has to satisfy the standards that are set by the international society. The study explored how teaching in the selected schools prepares the learners to function in the global village. Ten schools in the Chris Hani district were purposively selected as a sample for the study. Cognitive Load Theory was used as the springboard for the investigation and recommendations were made through the spectacle of the same theoretical framework. Data was collected through mixed methods design. Results showed that a number of schools in the sample are poorly resourced in human and material terms. There are a few schools where teaching and learning are properly facilitated.
\end{abstract}

Keywords: development, education for all, globalization, equality .teaching, schooling

\section{Introduction}

South Africa boasts good policies which can place education on a high pedestal if properly implemented. The study looks at the implementers of education, the teachers and how they facilitate education in the making and preparation of learners to take their positions in society. When the performance of a school is significantly below the expected level over a number of years, the phenomenon is referred to as underperformance. Research has shown that schools that pass the category of underperforming schools are engulfed by a plethora of disadvantages. One of the problems is the readiness of teachers, Dhlamini\& Mogari (2012 b). Over and above the difficulties that swamp these schools is the additional demand that time and global trends place upon all namely, the use of technology. The sum total of these place formidable burden on the functioning of the schools thus rendering them inefficient. On that note, the wish for equal education for all is annihilated.

\section{Theoretical Framework}

The study is couched in Cognitive Load Theory. Through Cognitive load the working memory of the individual is viewed as the most influential in determining the success of learning. The mental burden that is endured by an individual in the process of solving a given task can be explained through the cognitive load theory. Reasonable chunks of information are processed. This circumvents the risk of overloading the memory to a point where the amount taken cannot be assigned meaning.All memory that gets acquired has to be utilised within a short time .lgnoring this warning may lead to the complete loss of what has been gained. In emphasising the foregoing idea, Paas, Van Gogh\& Sweller (2010) aver that almost all information stored in the working memory and not put to test in the form of rehearsal gets lost. Brownlees \&Engle ( 2010) emphasises the importance of loading the mind with sizeable amounts to avoid the risk of losing some or even all the information if overloaded.

Dhlamini \& Mogari (2011) find a contrast in the fact that;

'Long-term memory has the capacity to permanently store huge chunks of domain-specific skills in the form of cognitive schemata."

But they find an answer in the views of Kirschner 2009 who argues that a schema can contain a big chunk as long as it is presented as a single unit. Classrooms should be arranged into group settings to allow automatic sharing that comes with proximity in seating. With sharing learners prompt one another deliberately or otherwise. This allows effective 
functioning of the mind and leads to optimal function.

Learning and Teaching study materials (LTSM's) should be presented in small chunks to allow complete assimilation without over burdening the mind. Even with the reality of wide syllabi and constant innovations in the Teaching and Learning environment there is the option of preparing materials so that they can be presented as single units. There is need for careful choice of teaching methods to allow full coverage of materials without exhausting the mind lest all information gets lost. It is of essence to spread the work over the whole class so that all can participate thus supporting one another. In this manner the load is spread fairly over the whole class thus allowing each learner to process just enough. Proper planning remains crucial to ensure that the load is manageable for each individual learner.

\section{Research Question}

What measures have been taken to foster equality and improve quality South schools?

\section{Literature Review}

The study looked at equality in education through the eye of the proponents of the Human Rights Declaration article 26.According to this article education is not just a right but a passport to development and this is accentuated by article 28 in stating that social and international order in which the rights and freedoms set forth in the declaration can be fully realized. The document on Education for all takes the argument further as it states that everyone is entitled not just to education but to decent education. Calderhead (2011) argues that section 29 (1) (a) of the South African constitution section (108) of 1996 speaks of equality in education. Provision of equal education in education is a step to equal society.

Based on the foregoing exposure the study looked at issues that can bring about equality in schools in the Chris Hani district. A number of issues that make schools and education have been considered. Calderhead 2011,Ramadikela 2012,Mahalngu 2008 agree on a number of aspects that make meaningful schooling and make quality education for all. Quality education for all inevitable results in equality in education. The following discussion presents a synopsis of views about schooling as it pertains in the Chris Hani district.

\subsection{School attendance and honouring of periods}

The National department of Education prescribes seven hours for a school day. A number of educators who participated in the study lived far from their work stations and also did not own their personal transport. Some of them live outside the normal route of the public transport which situation leaves them with one option: hitch hiking lifts to work. In $17 \%$ of these schools at least $25 \%$ of the educators lose a lot of time travelling to and from work. Sometimes one does not get a lift till about midday. In the words of one participant the "One has to decide whether to continue the trip to school or just go the other side of the road and hike the other direction back home." This leads to missing of teaching periods and in some instances a full day absence from school. (Journal of Education for Students Placed at Risk (JESPAR), Volume 2, Issue 4 (2007).Eighty ( $80 \%)$ of the teachers in the chosen schools are members of trade unions and they spend time on industrial action at frequent intervals. The sum total of these leaves them with less than the statutory teaching time and the objectives of the syllabus are left at stake

\subsection{Interpretation and implementation of syllabi}

A number of the teachers have poor understanding of the syllabus and a poor command of the language of learning and teaching (LOLT) and thus cannot implement the syllabi as expected. Answering the question of how much training they had in the new curricula and participants in some schools indicated that the total number of days was less than thirty(30).

Language is a conduit to understanding of the presented lessons. It gives meaning to the learning materials. Through language meeting of the educator, the student and the objectives of the lesson are negotiated. Learning materials and language make it possible for the syllabi to be brought to the rightful destination, the classroom. Proper interpretation and presentation of the syllabus prepares the learners for the world to function within the system. Mays (2004) argues that without proper use of materials and well planned learning activities students do not receive clear direction and cannot play their expected role in the composition of knowledge. 


\subsection{Accountability and commitment of parents to the education of their children}

Parent involvement is crucial in the successful management of schools. The South African government endorses this view through the South African Schools' Act(SASA) section 84 of 1996.In this Act, the role of parents is afforded a prominent position in the governance of schools, DOE (2003). Without parental involvement it is difficult for the School Management Team (SMT) of any given school to govern the school towards worthwhile performance. Ramadikela (2012) takes the debate further arguing that parental involvement is non negotiable and this has to be endorsed through compulsory training of parents by the schools so that all parents should know how they can contribute towards successful performance of their school. Schools that perform well show that a large number of parents are involved in school activities and have adequate knowledge of what their children require to perform at acceptable standards. This is endorsed by the views of Mahlangu (2008),Ramadikela (2012) who believe that parental involvement is key to the enhancement of the learners' intergrity. Schools that involve parents develop proper understanding between the school and the community. With such understanding problems with the some elements that are destructive to the culture of the school are curbed.

\subsection{Use of technological learning materials in schools.}

\subsubsection{Computers}

Most developed schools ensure that all learners have access to computers so that they can participate in the lesson and easily achieve the set objectives of the lesson. Computers make it easy for learners to research and get better understanding of what has been taught, de Heer Menlah (2010).Teachers use power point presentations which make it easy to move backwards and forwards during the presentation as the need arises. The slides can be kept in a safe place for later use. These can serve as easy reference both for the learners and the teachers

\subsubsection{SMS}

SMS, singular and bulk, is a technique that is used to relay urgent information to parents and learners. It can be used in reference to classroom related and other curricular activities Mbaza (2011).It is an efficient and cost effective method that reaches a large number of people. Although there is easy access to SMS and cell phones in the disadvantaged school communities, this technological asset is greatly underutilized and in this an opportunity is to communicate with the school community is missed.

\subsubsection{Blog}

Blogging can be used to communicate between educators and learners. This resource is a forum for learners to converse about their problems and assist one another Van Wyk, (2012). Teachers who make use of blog sites can post teaching material and announcements on the site. This gives the teachers opportunities to participate in the discussion amongst the students where they share their concerns and sometimes dissatisfaction about matters relating to their lessons. Matters that can culminate in serious problems and disruptions can be intercepted and resolved before they get out of hand.

\subsubsection{Cell phones}

The most available technological device in both advantaged and disadvantaged schools is the cell phone. It was discovered by de Heer Menlah (2012), that at least one cell phone can be found in each home even in the most underdeveloped communities. In most privileged schools the learners use the internet to gather information, even during classroom activities e.g. when searching for a definition. This device can also be used as a powerful tool to improve one's vocabulary and to find geographical locations. Lastly cell phones serve as a hub for social media e.g. WhatsApp and Facebook.

\subsubsection{Television}

Television sets are a source that is commonly used in modern schools" (Mbaza, 2011). Different educational shows on 
the sciences and different languages are broadcast on television and radio. Many high performing schools have lessons where the learners view these educational programs or videos and partake in the lesson as it advances. Learners go back and watch these lessons as need arises.

\subsubsection{Twitter}

Twitter is one of the relatively new devices that have emerged on the horizon of technology and some of the well performing schools have embraced it in their means of teaching and communication. Murray (2012) stipulates a number of advantages for using twitter. Amongst others is the skill to be focused on and being able to relay the main message in few words. Developing good manners (as "social networks are about etiquette" Murray: 2012) and tolerance for one another's opinions are life skills that can be learnt from twitter without anyone specifically giving instructions. These are some of the benefits that are gained by learners in performing schools while their counterparts in underperforming schools miss out on such opportunities.

Lee and McLaughlin (2010: 61) believe that technology tools enhance learning opportunities by allowing community building and encouraging participation amongst learners in their research. They also promote collaborative education and social presence, Mays (2011),Fataar (2009) aver that use of these technological devices is still at the very low ebb in poorly performing schools, the bulk of which is in previously disadvantaged communities.

\section{Research Methodology}

\subsection{Sampling}

The study used purposive sampling has been chosen because of the knowledge that the participants have about the study as well and their involvement in the purpose of the study.

Endorsing this view, Punch (2009) argues that purposive sampling helps the researcher to find and use information rich sources thus allowing direct access to the desired information. There is a characteristic that runs through all the selected participants. This concurs with Battaglia (2013) who asserts that

"The main objective of a purposive sample is to produce a sample that can be logically assumed to be representative of the population. This is often accomplished by applying expert knowledge to select in a non-random manner a sample of elements that represents a cross-section of the population."

The sample was made up of schools in the Chris Hani district, schools that have been functioning since the time of democracy. The district has both functional and non functional schools, a sequel of the former dispensation of inequality. With democracy in place for nineteen years and the call for equality having been made from the time of the birth of democracy, it is not unreasonable to imagine equality in education to be in place. Contact of groups from participating schools was avoided by ensuring a distance of at least sixty kilometres between schools. Gaigher (2006) argues that separation of participants prevents diffusion, contamination, rivalry and demoralisation among participants. This measure proved effective in making individual contribution by participants without emulating one another.

\subsection{Research design}

Flick,Von Kardoff and Steinke (2004: 146) contend that the research design is a plan used to collect and analyze evidence that will make it possible for the investigator to answer the questions that prompted one to undertake the research. Barbie and Mouton (2004) sum it up as the coherent group of methods that complement one another to deliver data and findings that reflect the research question and match the research purpose. The study was conducted through mixed methods design as promulgated by Creswell (2008), combining largely qualitative and some quantitative descriptions supported empirically by figures from the questionnaires.

\subsection{Data collection}

The researcher visited the schools according to the appointments and the arrangements agreed upon with the participants. All the teachers were interviewed individually to allow privacy and to present each participant the opportunity 
to speak freely Chisholm, (2009). Learners were put in focus groups that were arranged according to grades. Focus groups assist the participants to support one another. The ten principals and eight deputy principals had been supplied with questionnaires through post long before the field research was conducted. While most of them had returned their responses by mail a few returned them by hand post during my visit to their schools. The researcher also studied some documents like the code of conduct of the school. and the reports submitted to the heads of departments

\section{Findings}

Interpretation of the syllabus and presentation styles are at the helmet of classroom interaction and hence proper schooling. Most of the teachers in these schools still use methodologies that do not allow students to discover information on their own. Also some of the learning and teaching support materials are outdated.

Social media is a force to contend with and teachers cannot function outside the reality of learners. Sustaining the interest of learners is key to meaningful schooling. The following table gives a birds' eye view of the teachers' participation in social media.

Table showing the number of participants that used social media and the types of social media used.

\begin{tabular}{|c|c|c|c|c|c|}
\hline & None & Facebook & WhatsApp & Twitter & Mixit \\
\hline Number of Participants & $10 \%$ & $27 \%$ & $25 \%$ & $10 \%$ & $5 \%$ \\
\hline
\end{tabular}

Very little use is made of social media in the schools with some participants not even aware of how to partake in this space. In the interview it became clear that some of the participants do not see that need to have these in the schools. There were some strong views from some teachers who participated in the study that learners should not have their cell phones in their possession within the school premises.

\subsection{Internet access}

Table showing participants access of the internet

\begin{tabular}{|l|c|c|c|c|c|}
\hline & $\begin{array}{c}\text { Have access to } \\
\text { the Internet }\end{array}$ & $\begin{array}{c}\text { Do not have access } \\
\text { to the Internet }\end{array}$ & $\begin{array}{c}\text { Have access through } \\
\text { a cell phone }\end{array}$ & $\begin{array}{c}\text { Have access through } \\
\text { a computer }\end{array}$ & $\begin{array}{c}\text { Unable to } \\
\text { operate internet }\end{array}$ \\
\hline Number of Participants & $27 \%$ & $13 \%$ & $25 \%$ & $18 \%$ & $17 \%$ \\
\hline
\end{tabular}

Access to internet still remains a problem in the area due to poor electricity supply and difficulty with transport to reach the internet cafés as well as lack of skill to access information. The result is that $47 \%$ of the participants really struggle to access these services and $17 \%$ reported that they do have the skill to access information even if they were to be easy access.

\subsection{Computer literacy}

Table showing the number of interviewees that are computer literate and familiar with e-learning:

\begin{tabular}{|c|c|c|}
\hline $\begin{array}{c}\text { Participants have access to } \\
\text { a computer }\end{array}$ & $\begin{array}{c}\text { Participants that have training } \\
\text { in e-learning }\end{array}$ & $\begin{array}{c}\text { Participants that are interested in receiving } \\
\text { training in e-learning }\end{array}$ \\
\hline $36 \%$ & $7 \%$ & $72 \%$ \\
\hline
\end{tabular}

A formidable number of participants have no idea of what e-learning means; however they would like to learn. $36 \%$ of the participants have direct and easy access to the internet thus the methods deduced involving a computer would only benefit less than half of the individuals in underperforming schools, thus the goal (improving underperforming schools until they reach a level where they can be performing) would not be achievable.

\subsection{The use of technological resources in general}

Table showing the views of the participants' attitude towards technological resources in general: 


\begin{tabular}{|c|c|c|}
\hline $\begin{array}{c}\text { Participants who believe technological resources } \\
\text { can improve the learners performance: }\end{array}$ & $\begin{array}{c}\text { Participants who are willing to } \\
\text { use technological resources: }\end{array}$ & $\begin{array}{c}\text { Participants who wish that technology } \\
\text { should be used in schools: }\end{array}$ \\
\hline $36 \%$ & $37 \%$ & $79 \%$ \\
\hline
\end{tabular}

Technological resources are welcomed and recommended by most of the participants. There is also a large demand for these resources in general; once again if this cause could be embraced the government or large companies there would be vast improvement in the targeted schools.

\subsection{Concerns regarding technological resources}

Table showing the concerns participants had about the use of technological resources:

\begin{tabular}{|l|c|c|c|c|c|}
\hline & $\begin{array}{c}\text { Teachers struggling } \\
\text { with the new } \\
\text { equipment }\end{array}$ & $\begin{array}{c}\text { Learners who believe it } \\
\text { is impossible to adapt } \\
\text { to changes }\end{array}$ & $\begin{array}{c}\text { The cost of the } \\
\text { new equipment. }\end{array}$ & $\begin{array}{c}\text { The effect the use of the } \\
\text { resources will have on } \\
\text { the power supply }\end{array}$ & $\begin{array}{c}\text { Concern that there } \\
\text { may be theft of the } \\
\text { resources }\end{array}$ \\
\hline Number of participants & $64 \%$ & $5 \%$ & $12 \%$ & $15 \%$ & $28 \%$ \\
\hline
\end{tabular}

The use of technology poses a problem because a great proportion of the educators are at a very low functional level with technology. Compounding the problem is the scarcity of resources in their schools. Poor electricity access is another problem and this cannot be resolved by schools on their own. Theft and vandalism of the few facilities compounds the problem. Though government is on a bid to supply schools with the technology devices this is still at such low levels that it still features as television and radio news.

\subsection{Television}

In this day and age supply of computers, overheard projectors, internet connections and televisions should be common cause. Schools that do not perform well do not take advantage of this easily accessible asset. Children watch television at home and in their communities. They even go to the neighbours to watch programmes in the even though they are not available in their homes.

\section{Discussion}

From the findings of the study the researcher noted a few points and these points are discussed her below.

\subsection{Dearth of Teaching and learning materials}

The methods and learning equipment used are deficient or inappropriate for students to unleash their academic potential. In some schools students study science without a laboratory and without any knowledge of a pipette. This endorses an observation by Mbunyuza (2005). The same schools also have no computers and it is common to find that both educators and learners lack the functional knowledge of how to use a computer. According to the Tyson, Lee, Borman, and Hansen (2007: 243-270), 39\% of underperforming schools do not have learning material that adheres to the minimum requirements of the syllabus.

Research has deduced that students in underperforming schools do not receive clear directions or explanations from $25 \%$ of their educators. Four in every ten educators in $65 \%$ of the underperforming schools fail to interact with learners during lessons, and three in every ten educators in forty two of the schools in question experience problems with classroom management and sixty percent in forty nine percent of the schools in question experience problems in setting assessment tasks, from asking questions and other forms of formative assessment to setting tasks for summative assessment. Tyson, Lee, Borman, and Hansen (2007: 243-270).

\subsection{Prolonged dysfunctional organisation}

$79 \%$ of the schools in question have had poor management over an extended period of time. In some instances the administrative team has been marred by discord for a long period of time and major ongoing conflicts have occurred amongst the board of governors and school management, (Tyson, Lee, Borman, and Hansen (2007: 243-270). In some 
areas school governing bodies as prescribed by the South African Schools Act (SASA) have not been established Ndou (2012:109)

\subsection{Instability in some school leadership teams}

It is a cause of concern that some underperforming schools are plagued by weak leadership which is a result of fear among some members of the School Management Teams (SMT's)to stand firm in correcting whatever untoward behaviour from the learners and educators as well as possible loss of popularity from the communities they purport to serve Ramadikela (2012:94).Some members of the SMT's would rather be in conflict with the principals or other members within the team than lose face from the learners and any other group that is against the leadership of the schools.

\subsection{Frequent fluctuations in enrolment and staffing}

These schools have a $20 \%$ higher teacher mobility rate than schools that perform sufficiently, the learners have multiple teachers in a year and it is common for the schools to remain without a teacher for a given subject for a number of months.

\subsection{Parental involvement}

Parents hardly partake in the education of their children be it through homework, visiting the school or contributing time or resources. Mahlangu(2008). Parents do not interact with teachers on a regular basis to enquire about the problems their children may be facing or to find out how they can support the children. Education needs much more than just teachers, children and classroom engagement. No schooling can succeed without parents playing their active role. On the parent involvement is high and noticeable in high performing schools.

\section{Recommendations}

South Africa purports to bring about quality to all. Given the history of the country, quality alone cannot go far enough in closing the gap between people. Equality of all is still the goal to aspire for to make a better pool of well educated people. The Government and private business are the main beneficiaries of good education and unless all learners. This points to the need for both institutions to hold hands and direct their efforts and funds to provide resources of material and human nature to the schools. Teacher appropriacy and efficiency should always be placed in the forefront in the provision of education. The need for proper infrastructure should also rank high in turning situation around. School should be centres with stimulating atmosphere.

Table showing the suggestions made by the sample group about how underperforming schools can be improved

\begin{tabular}{|c|c|c|c|}
\hline & $\begin{array}{c}\text { Commitment of the parents, students, } \\
\text { educators and school governing body } \\
\text { should be encouraged }\end{array}$ & $\begin{array}{c}\text { Better qualified teachers should } \\
\text { be employed }\end{array}$ & $\begin{array}{c}\text { Teachers should be paid } \\
\text { higher salaries }\end{array}$ \\
\hline Number of participants & $27 \%$ & $29 \%$ & $17 \%$ \\
\hline & Libraries should be made accessible & $\begin{array}{c}\text { The culture of learning has to be } \\
\text { instilled and discipline has to be } \\
\text { inculcated in learners }\end{array}$ & $\begin{array}{c}\text { Support services and } \\
\text { enhancement strategies } \\
\text { classes for struggling learners }\end{array}$ \\
\hline Number of participants & $31 \%$ & $23 \%$ & $33 \%$ \\
\hline
\end{tabular}

Findings show that there are ways in which the underperforming schools can be brought to speed. Provincial departments of education together with the national department should join hands with all the community stakeholders to improve education. Programs like Matric- upload and others from the SABC and other parastatal institutions should be brought in. The commitment of all the individuals involved in the school can be exercised through SMS technology, social media and blog sites to name a few. For example social media could be used by the educators and school governing body to notify the parents about any special events that may be occurring at school such as a parents evening. 


\section{Conclusion}

Inequalities that are evident in the provision of education continue to dampen whatever effort is made to cure the ills that embed education. Such inequalities are evident in the provisioning of education. It is incumbent upon the South African government to work hard to minimise the gap between the well resourced and the poorly resourced schools. This does not only refer to physical resources also goes for the attitude of the teachers and learners in making success of schooling and learning. With the commitment of government and the willingness of the school leaders it is a possible to turn the situation around. Teachers need to be part in the planning of improvement strategies. They should be in the fore front in the implementation of a process. Every opportunity, every learning material that is accessible should be used to the improvement of the learners who find themselves in not so fortunate environments.

\section{References}

Battaglia, M. (2008) Purposive sample. In P. Lavvraska (ed) Encyclopaedia of surety research methods (p645).Thousand Oaks, C.A: Sage Publications, Inc. doi: http://dx.doi.org/10.44135/9781412963947.n419

Brownlees C.T.\& Engle,R. ( 2010) Volatility ,Correlation and tails for systemic Risk measurement .This Draft : May 2010 http: I/ssm.com/abstract -1611229

Cohen L, M Lawrence, K Morrison, (2009) $6^{\text {th }}$ edition, New York: Routledge

Chisholm, L.2009. An overview of research, policy and practice in teacher supply and demand 1994- 2008, Teacher Education in South Africa Series. Cape Town: HSRC Press.

Creswell, J. W. (2008). Qualitative, quantitative and mixed methods approach.

Department of Education (DOE) 2003.Review of Governance in South African Public Schools. Report of the ministerial review on school governance. Pretoria : Government Printer.

de Heer Menlah F.K.(2010) Exploring the factors that hinder and help the development of internet access in Africa. Ubiquity archive, New York . Vol.(4)2002

Dhlamini, J.J. \& Mogari, d. (2012b) Using a context -based problem solving instruction to promote social justice in high school mathematics classroom. In S. Niewoudt, D Laubscher \& J Dreyer (eds) Proceedings of the $18^{\text {th }}$ National Congress of the Association for Mathematics .Vol(1) pp.108-119.

Fataar, A.(2009). Youth becoming across the rural-urban landscape: The case of the Fuzile Ali at a Muslim community school in Cape Town in Southern African Review of Education (SAERA) Volume 15, issue 2, 2009.

Flick, U, van Kardorff E, S Stienke,I (Eds) (2004). A companion to Qualitative Research. London: Sage.

Gaigher, E. (2006) The effect of a structured problem- solving strategy on performance and conceptual understanding of physics.A study in disadvantaged South African schools. unpublished doctoral dissertation .University of Pretoria. Available from http/lupetd.ac.za/ thesis/available/etd-02022006-160908/

Lee, Y.C. \& McLaughlin M.P. 2(007). Proceedings of the $20^{\text {th }}$ International Technical Metting of the Satellite Division of the Institute of Navigation (IONGNSS 2007) September 25-28,2007 Forth Warth Convention Center Forth Worth, TX

Lewis, L Kim, YA Bey, J.A (2011) Teaching and teacher education journal volume 27 - pp 221- 234 Teaching practices and strategies to involve inner city parents at home and in the school.

Mahlangu, R (2008). The effective functioning of a school governing body: a case study. Pretoria: UNISA

Maphalala, M. (2012). The role of teaching Practice in the Initiation of Student Teachers into the Teaching Profession: A Student's Perspective in an ODL content. Proceedings of the 2012 Annual Conference held at Mpekweni Beach Resort : 17-20 January 2012.

Mays, T.J. ( 2004). from policy to practice: an evaluation of the Unisa National Professional Diploma in Education from the perspective of social critical theory. Unpublished Med dissertation. Pretoria; Unisa.

Mbaza, N.E. (2011). An unpublished MEd dissertation presented at Vista University - Bloemfontein.

Mbunyuza NMM.( 2005).Learner support systems for Grade10-12 learners in South African schools.

Mouton,J.\& Barbie, E. 2004. The practice of Social Research Open Universty Press Fourth Reprint..

Murray, J 2012. Independent Education. Winter 12 pp.9r 92

Ndou, N. 2012. Challenges Facing School Governing Bodies in the implementation of Funded Policies in the Vhembe District, an unpublished dissertation. Pretoria: UNISA.

Punch, F.K. 2009. Introduction to Research methods in Education. Sage Publications. LTD.London.

Ramadikela, M.R. 2012. The management of parent involvement in historically disadvantage secondary schools, in west district, Gauteng. Med dissertation.

Slavin, R.E (2009) Educational Psychology: theory and practice 9th edition. Pearson education International, USA: New Jersey

Tyson, W. Lee, R. Borman, K.M. \&Hansen,M.A. Science, technology, Engineering and Mathematics (STEM) Pathways: High school Science and Math, Coursework and Post Secondary Degree Attainment. Journal of Education for Students Placed at Risk Vol 12, Issue 3, 2007. Pp243-270.

Van Wyk,M. 2012 Teacher Efficacy: The use of cooperative Learning techniques in Economics in the Free State Secondary schools: International Journal of EducationScience 4(3) pp.187-195 